\title{
FIRST REPORT OF A HELMINTH INFECTION FOR BRYDE'S WHALE, BALAENOPTERA EDENI ANDERSON, 1878 (CETACEA, BALAENOPTERIDAE)
}

\author{
Roberto Magalhães Pinto ${ }^{1}$, Luís C. Muniz-Pereira ${ }^{1}$, Vinicius C. Alves ${ }^{2}$ and Salvatore Siciliano ${ }^{2}$
}

\begin{abstract}
Acanthocephalans represented by Bolbosoma capitatum (von Linstow, 1880) Porta, 1908 were recovered from a single specimen of Bryde's whale (Balaenoptera edeni) from the coast of the state of Rio de Janeiro, Brazil. This is a new host record for the parasite and the first case of infection by helminths in Bryde's whales.

Resumo - Acantocéfalos representados por Bolbosoma capitatum (von Linstow, 1880) Porta, 1908 foram coletados de um exemplar de baleia-de-Bryde (Balaenoptera edeni) na costa do estado do Rio de Janeiro, Brasil. Este é um novo registro de hospedeiro para o parasita e o primeiro caso de infecção por helmintos registrado na baleia-de-Bryde.
\end{abstract}

Key words: Helminths, whales, Balaenoptera edeni, acanthocephalans, Bolbosoma capitatum, Brazil.

\section{Introduction}

Despite their large size making necropsies difficult and the fact that they are protected by law against capture, sampling of helminths parasitizing whales, in Brazil and other countries, are relatively frequent.

The present paper deals with the report of an acanthocephalan species, Bolbosoma capitatum (von Linstow, 1880) Porta, 1908, parasitizing a specimen of Bryde's whale (Balaenoptera edeni Anderson, 1878) from the Brazilian coast. According to Nowak (1999), certain populations of this whale live in waters of high productivity near shore, whereas others are mainly pelagic. Specimens of B.edeni have a tendency to approach ships and are relatively deep divers. They feed mainly on small schooling fish, but in some areas their diet consists extensively of shrimp-like crustaceans.

No parasites have been previously recorded from this particular host species. The acanthocephalan Bolbosoma capitatum has been recorded in the short-finned pilot whale (Globicephala melas), the false killer whale (Pseudorca crassidens), the rough-toothed dolphin (Steno bredanensis) and the sperm whale (Physeter macrocephalus) occurring in the Atlantic Ocean and Mediterranean Sea. The intermediate hosts of this parasite are unknown (Petrochenko, 1971).

\section{Material and Methods}

On February 26, 2004, a single specimen (sex not confirmed) of Bryde's whale (Balaenoptera edeni), $9.50 \mathrm{~m}$ long, was found stranded dead on the beach near Lagoa do Paulista, Quissamã $\left(22^{\circ} 06^{\prime} 24^{\prime \prime}\right.$ S, 41 $\left.28^{\prime} 20^{\prime \prime} \mathrm{W}\right)$, state of Rio de Janeiro, Brazil. The carcass was examined for parasites. The worms were preserved uncompressed in $70^{\circ} \mathrm{GL}$ ethanol, in situ. Under laboratory conditions, some were processed for study, unstained, dehydrated in alcohol $\left(80^{\circ}-100^{\circ} \mathrm{GL}\right)$, clarified in glacial acetic acid and phenol and reversibly returned to the original preservative. Photomicrographs were obtained from a Zeiss bright-field microscope in a Differential Interference Contrast (DIC) system. Classification of the acanthocephalans follows Amin (1998) and that of the host is in accordance with Mead and Brownell (1993) and Nowak (1999). Measurements taken are in millimetres $(\mathrm{mm})$ unless otherwise indicated. Some specimens were deposited in the Helminthological Collection of the Oswaldo Cruz Institute (CHIOC), Rio de Janeiro.

\section{Results}

Seventy-four acanthocephalans identified as Bolbosoma capitatum were recovered from the digestive tract of the Bryde's whale. This is the first case of a helminth infection in this host.

Bolbosoma capitatum (von Linstow, 1880) Porta, 1908 (Figures 1a-d ).

Brief morphometric data based on five adult males and five adult females: Polymorphidae. Body stout, $2-3 \mathrm{~cm}$ long in males and $3-4 \mathrm{~cm}$ in females. Width of body at the middle region, 2.1 to 2.3 in males and 2.4 to 3.6 in females. Proboscis cylindrical, truncated-rounded anteriorly, broadest near its base, with 16 to 18 rows of 9 to 10 hooks each. Bulbous posterior cephalic bulb 0.90 1.15 long, 2.8 to 3.0 wide, with 7 to 12 circles of at least 34 to 52 spines, each measuring 0.09 to 0.17 long. Trunk constriction 1.80 to 2.4 long. Ripe eggs fusiform with polar prolongation of fertilization membrane, 0.12 to 0.15 long, 0.02 to 0.03 wide.

\section{Taxonomic summary:}

Definitive host: Balaenoptera edeni Anderson, 1878, Cetacea, Balaenopteridae; common name: Bryde's whale- NHR.

\footnotetext{
${ }^{1}$ Instituto Oswaldo Cruz, Departamento de Helmintologia, Laboratório de Helmintos Parasitos de Vertebrados. Av. Brasil, 4365, Manguinhos, Rio de Janeiro, RJ 21040-900 Brazil.

${ }^{2}$ Grupo de Estudos de Mamíferos Marinhos da Região dos Lagos (GEMM-Lagos), Laboratório de Ecologia, Departamento de Endemias Samuel Pessoa, Escola Nacional de Saúde Pública/FIOCRUZ. Rua Leopoldo Bulhões, 1480-térreo, Manguinhos, Rio de Janeiro, RJ 21041-210 Brazil.
} 
Site of infection: intestine

Locality: Praia da Lagoa do Paulista, Quissamã, state of Rio de Janeiro, Brazil.

Specimens deposited: CHIOC no. 35304 (wet material) 36449 a-c (whole mounts).

Comment: Taking into account that the worms were fixed uncompressed, other morphological parameters could not be properly evaluated. Nevertheless, present results related to the two most important specific characters, the interbulbar spines and proboscis armature, are in accordance with data previously referred for B. capitatum.

\section{Discussion}

In Brazil, helminth surveys of cetacean hosts refer to the nematodes Anisakis insignis, A. typica, Halocercus brasiliensis parasitizing the boto (Inia geoffrensis) and the tucuxi (Sotalia fluviatilis), respectively (Vicente et al., 1997), Anisakis physeteris, Pseudoterranova sp., Crassicauda crassicauda in the pygmy sperm whale (Kogia breviceps), the sperm whale (Physeter macrocephalus), the sei whale (Balaenoptera borealis) as well as in the fin whale (B. physalus) (Santos and Lodi, 1998; Muniz-Pereira et al., 1999), and A. simplex in the false killer whale (Pseudorca crassidens) (Santos et al., 1996; Andrade et al., 2001).
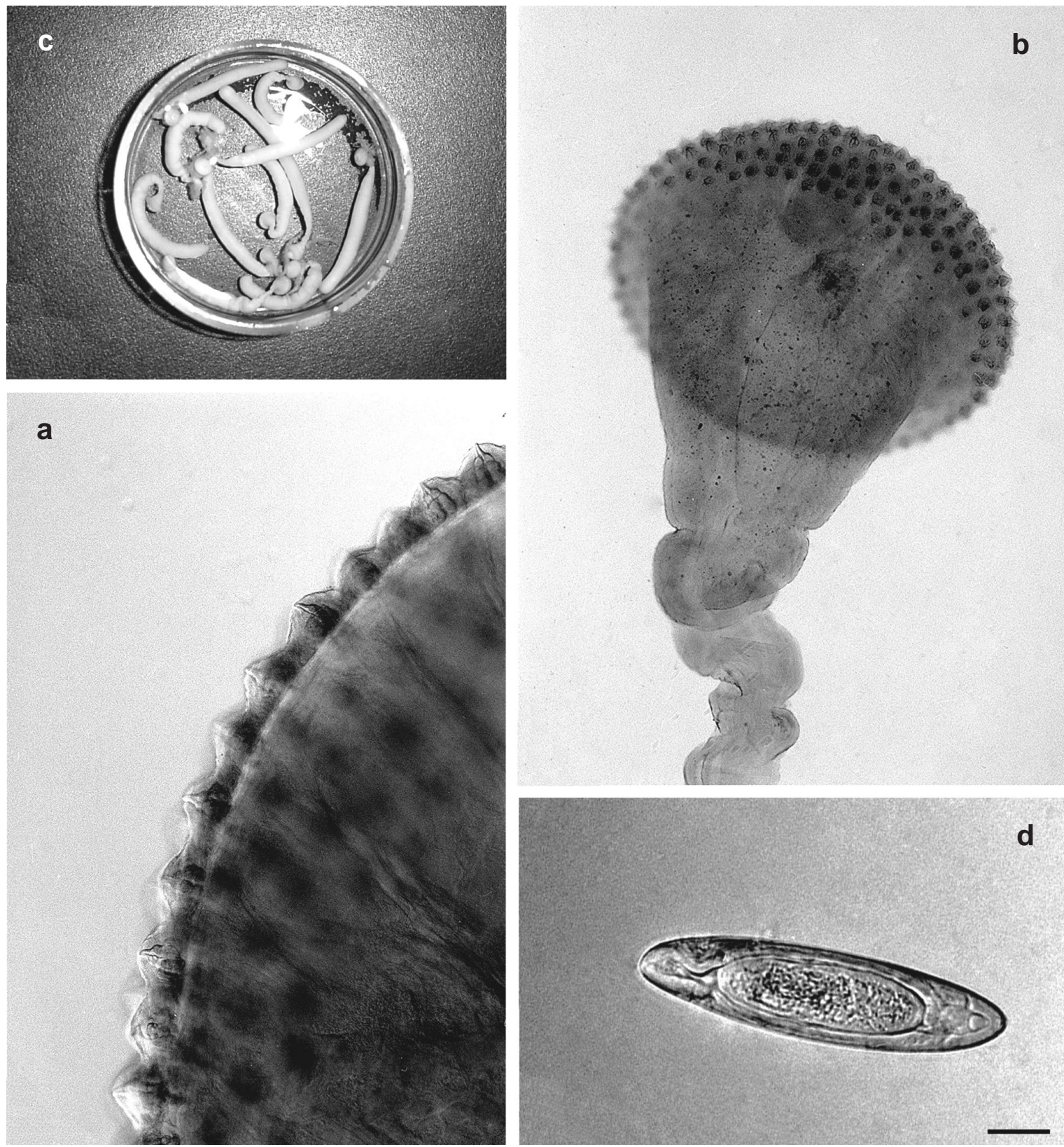

Figure 1. Bolbosoma capitatum. (a) adult unmounted specimens, bar $=0.8 \mathrm{~mm}$; (b) proboscis, bar $=0.5 \mathrm{~mm}$; (c) detail of spines of the proboscis, bar $=0.02 \mathrm{~mm}$; $(\mathrm{d}) \mathrm{egg}, \mathrm{bar}=0.02 \mathrm{~mm}$. (Bar of $1 \mathrm{~d}$ is common to figures $1 \mathrm{a}-\mathrm{c})$. 
Digeneans were represented by Braunina cordiformis in $S$. fluviatilis, B. cordiformis and Amphimerus lancea in the common dolphin Delphinus delphis, Lecithodesmus goliath in the sei whale (B. borealis), Ogmogaster antarticus in sei and fin whales (B. borealis and B. physalus), respectively, Nasitrema sp. and B. cordiformis in Tursiops truncatus and B. cordiformis in Steno bredanensis (Travassos et al., 1969; Santos et al., 1996; Muniz- Pereira et al., 1999).

The only cestode species so far referred in Brazil is Tetrabothridae sp. in the false killer whale (Andrade et al., 2001). The acanthocephalan Bolbosoma capitatum was referred in this latter host (Andrade et al., 2001) and in the long-finned pilot whale (Machado-Filho, 1964) whereas B. turbinella has been reported from the sei whale (Machado-Filho, 1964; Muniz-Pereira et al., 1999).

Overseas, acanthocephalans of the genus Bolbosoma have been regularly reported from cetaceans: Bolbosoma sp. has been recovered from the pygmy (K. breviceps) and dwarf sperm whales (K. sima), respectively, in the Caribbean (Cardona-Maldonado and Mignucci-Giannoni, 1999), from striped dolphins (Stenella coeruleoalba) on the Spanish Atlantic coast (Abollo et al., 1998), from belugas (Delphinapterus leucas) in the Gulf of St. Lawrence, Canada (Measures et al. 1995), and from the sperm whale in Prince Edward Island, Canada (Hoberg et al., 1993), from the blue whale (B. musculus) in the North Pacific Ocean (Measures, 1993). Bolbosoma balaenae has been reported from the eastern Pacific gray whale (Eschrichtius robustus) on the northern California coast (Dailey et al., 2000), from B. musculus in Antarctic and Arctic waters, North Atlantic Ocean and Tasman Sea (Measures, 1993). Bolbosoma capitatum has been reported from the false killer whale in West Australia, Katsumura Bay, Japan and off Vancouver Island, British Columbia, Canada (Edmonds 1987; Kicuchi and Nakagima 1993; Amin and Margolis, 1998), from longfinned pilot whales off the Faeroe Islands (Balbuena and Raga 1993, 1994), from sperm whales in Canada (Hoberg et al., 1993), from the short-finned pilot whale (G. macrorhynchus) in the Caribbean (Giannoni-Mignucci et al., 1998), and from the common dolphin on the coast of England and Wales (Gibson et al., 1998). Bolbosoma nipponicum has been recorded in the minke whale ( $B$. acutorostrata) in the North-Western Pacific Ocean and $B$. musculus in the Northwest and Northeast Pacific Ocean (Uchida and Araki, 2000; Measures, 1993). Bolbosoma turbinella has been reported from the blue whale in Arctic and Antarctic waters, Northwest Pacific Ocean, Northwest Atlantic Ocean and North Atlantic Ocean (Measures, 1993), Bolbosoma turbinella and B. physiteris (= B. capitatum) from the sei, minke and sperm whales in the Antarctic Region (Dailey and Vogelbein, 1991); Bolbosoma brevicolle from blue whales in the North, Southeast, South, and Southwest Atlantic Ocean, Antarctic and Arctic waters (Measures, 1993); Bolbosoma hamiltoni from blue whales in the South Atlantic Ocean and Arctic waters, from the spinner dolphin (Stenella longirostris) in La Paz Bay, Baja California Sur, Mexico (Measures, 1993, Aguilar-Aguilar et al., 2001); Bolbosoma paramuschiri from blue whales in the Northwest
Pacific Ocean (Measures, 1993); Bolbosoma vasculosum from pygmy killer whales (Feresa attenuata) in the Caribbean and common dolphins in Madeira, Portugal (MignucciGiannoni et al.,1998; Costa et al., 2000).

The finding of B. capitatum infecting the Bryde's whale specimen in Brazil represents a new host record for the parasite as well as it reports the first helminth infection in this whale species.

\section{Acknowledgements}

To Dalila Mello and Eduardo J. Jardim, head of Parque Nacional da Restinga de Jurubatiba, for local support during necropsy and recovery of the Bryde's whale's carcass; to Luiz Antônio, from Secretaria de Meio Ambiente de Quissamã for calling our attention for the stranded whale; to Bárbara Berón-Vera, (Centro Nacional Patagónico, Argentina), and Juliana Marigo (Universidade de São Paulo) for the review of the manuscript; to Conselho Nacional de Desenvolvimento Científico e Tecnológico (CNPq), for partial financial support to R. M. Pinto and to Bruno Eschenazi Silveira, Laboratório de Imagens, Instituto Oswaldo Cruz, for technical assistance with the figures. Mônica Borobia, Wyb Hoek and Nélio B. Barros kindly revised the final English version.

\section{References}

Abollo, E., Lopez, A., Gestal, C. Benavente, P. and Pascual, S. (1998) Macroparasites in cetaceans stranded on the northwestern Spanish Atlantic coast. Diseases of Aquatic Organisms 32(3): 227-231.

Aguilar-Aguilar, R., Moreno-Navarrete, R.G., SalgadoMaldonado, G. and Villa-Ramirez, B. (2001) Gastrointestinal helminths of the spinner dolphin Stenella longirostris (Gray, 1828) (Cetacea: Delphinidae) stranded in La Paz Bay, Baja California Sur, Mexico. Comparative Parasitolology 68(2): 272-274.

Amin, O.M. and Margolis, L. (1998) Redescription of Bolbosoma capitatum (Acanthocephala: Polymorphidae) from false killer whale off Vancouver Island, with taxonomic reconsideration of the species and synonymy of B. physiteris. Journal of Helminthology 65(2): 179-188.

Andrade, A.L.V, Pinedo, M.C. and Barreto, A.S. (2001) Gastrointestinal parasites and prey items from a mass stranding of false killer whales Psedorca crassidens, in Rio Grande do Sul, Southern Brazil. Brazilian Journal of Biology 61(1): 55-61.

Balbuena, J.A. and Raga, J.A. (1994) Intestinal helminths as indicators of segregation and social structure of pods of long-finned pilot whales (Globiocephala melas) off the Faeroe Islands. Canadian Journal of Zoology 72: 443-448.

Cardona-Maldonado, M.A. and Mignucci-Giannoni, A.A. (1999) Pygmy and dwarf sperm whales in Puerto Rico and the Virgin Islands, with a review of Kogia in the Caribbean. Caribbean Journal of Science 35(1-2): 29-37.

Costa, G, Chubb, J.C. and Veltkamp, C.J. (2000) Cystacanths of Bolbosoma vasculosum in the black scabbard fish Aphanopus carbo, oceanic horse mackerel Trachurus picturatus and common dolphin Delphinus delphis from Madeira, Portugal. Journal of Helminthology 74: 113-120. 
Dailey, M.D. and Vogelbein, W.K. (1991) Parasite fauna of three species of Antarctic whales with reference to their use as potential stock indicators. Fishery Bulletin 89(3): 355-365.

Dailey, M.D., Gullant, F.M.D., Lowenstine, L.J., Silvagni, P. and Howard, D. (2000) Prey, parasites and pathology associated with the mortality of a juvenile gray whale (Eschrichtius robustus) stranded along the northern California coast. Diseases of Aquatic Organisms 42(2): 111-117.

Edmonds, S.J. (1987) A note on the occurrence of Bolbosoma capitatum (Linstow, 1880) (Acanthocephala) from a false killer whale stranded on the coast of Western Australia. Records of the West Australian Museum 13: 317-318.

Gibson, D.I., Harris, E.A., Bray, R.A., Jepson, P.D., Kuiken, T., Baker, T. and Simpson, V.R. (1998) A survey of the helminth parasites of cetaceans stranded on the coast of England and Wales during the period 1990-1994. Journal of Zoology 244(4): 563-574.

Hoberg, E.P., Daoust, P.Y. and Mcburney, S. 1993. Bolbosoma capitatum and Bolbosoma sp. (Acanthocephala) from sperm whales (Physeter macrocephalus) stranded on Prince Edward Island, Canada. Journal of the Helminthological Society of Washington 60(2): 205-210.

Kikuchi, S. and Nakajima, M. (1993) Bolbosoma capitatum (Acanthocephala) from false killer whales, Pseudorca crassidens, and its pathogenicity. Japanese Journal of Parasitology 42(5): 398-408.

Machado Filho, D.A. (1964) Contribuição para o conhecimento do gênero Bolbosoma Porta, 1908 (Palaeacanthocephala, Polymorphidae). Revista Brasileira de Biologia 24(3): 341-348.

Mead, J.G. and Brownell, R.L. (1993) Order Cetacea. Pages 349-364. in Wilson, D.E. and Reeder, D.A.M. (Eds) Mammal species of the world. Smithsonian Institution Press Washington, DC.

Measures, L.N. (1993) Annotated list of metazoan parasites reported from the blue whale, Balaenoptera musculus. Journal of the Helminthological Society of Washington 60(1): 62-66.

Measures, L.N., Beland, P., Martineau, D. and Guise, S. (1995) Helminths of an endangered population of belugas, Delphinapterus leucas, in St. Lawrence estuary, Canada. Canadian Journal of Zoology 73: 1402-1409.

Mignucci-Giannoni, A.A., Hoberg, E.P., Siegel-Causey, D. and Williams Jr, E.H. (1998) Metazoan parasites and other symbionts of cetaceans in the Caribbean. Journal of Parasitology 84(5): 939-946.

Muniz-Pereira, L.C., Vicente, J.J. and Noronha, D. (1999) Helminths parasites of whales in Brazil. Revista Brasileira de Zoologia 16(Supl.2): 249-252.

Nowak, R.M. (1999) Walker's Mammals of the World II. The Johns Hopkins University Press, London.

Petrochenko, V.I. (1971) Acanthocephala of Domestic and Wild Animals II - Israel Program for Scientific Translations, Jerusalem

Santos, C.P. and Lodi, L. (1998) Occurrence of Anisakis physeteris Baylis, 1923 and Pseudoterranova sp. (Nematoda) in the pygmy sperm whale Kogia breviceps (De Blainville, 1838) (Physeteridae) in northeastern coast of Brazil. Memórias do Instituto Oswaldo Cruz 93(2): 187-188.

Santos, C.P., Rohde, K., Ramos, R., Di Beneditto, A.P. and Capistrano, L. (1996) Helminths of cetaceans on the southeastern Coast of Brazil. Journal of the Helminthological Society of Washington 63(1): 149-152.

Travassos, L., Freitas, J.F.T. and Kohn, A. (1969) Trematódeos do Brasil. Memórias do Instituto Oswaldo Cruz 67: 1-886.

Uchida, A. and Araki, J. (2000) Ectoparasites and endoparasites in the minke whale (Balaenoptera acutorostrata) from the North-Western Pacific Ocean. Journal of the Japanese Veterinary Medical Association 53(2): 85-88.

Vicente, J.J., Rodrigues, H.O., Gomes, D.C. and Pinto, R.M. (1997) Nematóides do Brasil. Parte V: Nematóides de mamíferos. Revista Brasileira de Zoologia 14(Supl.1): 1-452. 